bahasa \& sastra, Vol. 14, No.1, April 2014

\title{
ISSUES OF FEMINISME IN THE PATRIARCHAL SOCIETY AS PORTRAYED IN ANANTA TOER'S “THE GIRL FROM THE COAST”
}

\author{
Wildona Zumam \\ Universitas Madura \\ Address: Jln. Raya Panglegur KM. 3,5 . Pamekasan -Madura 69371 \\ E-mail: houseofmumtaz@yahoo.co.id
}

\begin{abstract}
This article revolves around the issues of feminism in a novel. Issues of feminism are interesting to analyze because they have been leading issues in many societies. There are two problems addressed, namely what issues of feminism are and how the main character reacts to her condition in the novel. Marxist and feminism theories are used to analyze the position of the main character. Results indicate the girl's tiresome yet fruitless struggle against the patriarchal oppressions in her unequal marriage and there is no victory for a woman except she is willing to leave her life behind. The novel is suitable for use in literature and also good for reading activities in an intermediate to advanced English class.
\end{abstract}

Key Words: feminism, patriarchal society, novel.

\begin{abstract}
Abstrak
Studi ini menitikberatkan pada isu-isu feminisme. Isu feminisme sangat menarik untuk dianalisis karena feminisme telah menjadi permasalahan yang mengemuka dalam masyarakat di dunia yang tengah berubah sejak peralihan abad. Ada dua permasalahan di novel ini yaitu bagaimana isue feminisme dan tokok utama bereaksi pada kondisi mereka yg tergambar dalam novel tersebut teori Marxisme dan feminisme dipergunakan untuk menganalisis tokoh utama dalam novel. Setelah itu ada kesimpulan yang mengacu pada masalah-masalah yang diutarakan GadisPantai menggambarkan perjuangan tokoh utamanya yang melelahkan tetapi tidak berbuah apa-apa melawan penindasan patriarki di dalam pernikahannya yang tidak setara dan tidak ada kemenangan bagi perempuan yang berjuang melawan penindasan patriarki, kecuali ia bersedia meninggalkan kehidupannya. Novel-novel ini cocok untuk digunakan dalam kelas sastra Bahasa Inggris tetapi juga baik sekali untuk kegiatan membaca dalam kelas bahasa Inggris tingkat mahir.
\end{abstract}

Kata-Kata Kunci : feminisme, masyarakat patriarkal ,novel.

\section{INTRODUCTION}

Literature is not only born by many phenomena of the bold life, but also the awareness of the writers. Literature as something imaginative, fictional, and inventive also has to serve missions which have to be completed. The authors, when creating their products of writing, do not only create something beautiful but also have the willingness to apply their minds, opinions, and impressions to the writings. At the same time the literature itself also comes in different forms, as poem, phrase, short story, and novel. Each of those forms is interesting to read and analyze, but this article prefer to read and analyze a novel to other literature products. I chooses to study novel because by reading a novel, I can 
enjoy the details of the story, understand deeply about the alter egos and problems portrayed in the story.

A novel is a product of literary work which serves the figures and shows the sequences of story following its format. However, the sequence of the story can be inspired by the reality of life and moreover a novel has a task to educate the soul of its reader or even human experience. The novel as a part of literary work has the function to mention dulceet utile which means pleasure and benefit for its readers through the depictions of real life. As a fiction, the novel usually contains many experiences that offer problems of life. Thus a novel must be built as an interesting story having cohesive building structures and esthetic purposes.

As Magnis-Suseno (2003:5) mentions in his book, Karl Marx's Thinking,the term 'Marxism' itself refers to the campaign of Karl Marx's teachings mainly pioneered by his colleague, Friendrich Engels and a leading theorist of Marxism, Karl,Kautsky .Marxism also has a great deal of influence in literary criticism. The so-called 'Marxist literary criticism" "is a loose term describing literary criticism informed by the philosophy or the politics of Marxism" (Wikipedia,2008). Marxist criticism has a large influence on feminism, new historicism, and cultural studies.

From One Indonesian feminist, Nyoman Kutha Ratna defines Feminism as "women's struggles to fight for their rights as a social class" (Ratna ,2009:184)The purpose of feminism is balanced gender interrelation. In the broadest sense, feminism is women's movement to reject anything that is marginalized, subordinated, and subjugated by the dominant cultures, either in politics, economy as well as social life in general. Riant mentions that gender inequalities refer to a system and structure wherein men and women have both become victims. Thus in order to comprehend the differences in gender that have caused such inequalities, one should take a look at the several manifestations of inequalities, as follows: Marginalization,Subordination and stereo type.Marginalization is the selection process that in turn yields economic poverty for women. There are several mechanisms of this marginalization process due to gender differences. Subordination refers to the attitudes, assumptions or social actions that place women on lower positions. Stereotype refers to the labeling or marking onto a certain group, subjecting it to negative behavior or judgment. Stereotype can be based on gender perspective.

In a narrower sense, in literature that is, feminism is linked to ways to comprehend literary works in relation to the process of production as well as perception. Women emancipation therefore is an aspect of equality in rights. In contemporary social science the more common term is gender equity (Ratna,2009:184).

The Girl from the Coast is a novel that tells us a story about a village girl who is drawn into a high-class, aristocratic life. She is given an aristocratic title, and then she has to go into a fixed marriage with a man of aristocratic status. The girl is given a new name, Mas Nganten. When Mas Nganten eventually falls in love with her husband, she is treated in such an improper way. She then realizes that she is just made as a 'temporary wife' while her husband is looking for another woman of his own stature to be his real wife. The interesting point in this novel is the description of Indonesian women - or Javanese women in particular - as being put in a weak position and as being poor and foolish.

Nowadays women have more freedom in their lives, such as in choosing their careers. Women are also freer now to choose how to live their lives, as is should be since a woman deserves the same 
appreciation and respect as does a man. Reading this novel, one shall better appreciate freedom in the life of woman. Again this is why this article is interested to discuss issues of feminism as portrayed in that novel.

\section{METHOD}

The method must be suitable for the literary analysis approach adopted in this article is the qualitative research method. Saurces of data is the Novel The Girl from The Coast by Pramoedya Ananta Toer was published by Hyperion in New York 2002, it has 280 pages long, translated into English, and the story is set in a coastal region in Central java. In here also used primary and secondary data.
Data are collected through two sources : primary sources (the novel) and secondary sources (reference books, internet, based review, etc). Procedures of data collection is bibliography technique, consulting and recording.

After all the data had been collected and catagorized, the next step was analyze the data. The data being analyzed is the primary data, that comes in the form of quoted words and sentences from the novel, viwed from a feminist perspective. While instances of secondary data are used as reference to suport the arguments made by the resercher in the analysis. This is the logical framework as follows:

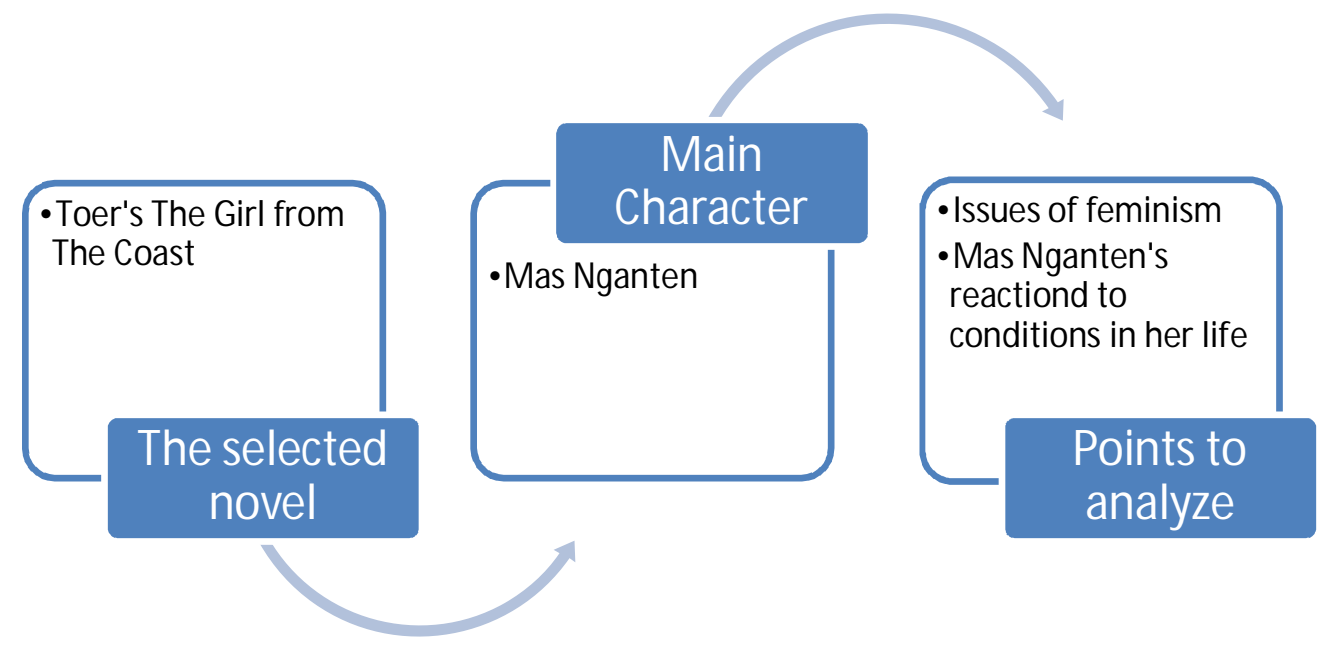

RESULTS AND DISCUSSION

1. Issues of feminism in the life of The Girl a.k.a Mas Nganten

In this particular novel the main character underwent a 'social promotion'; suddenly finding herself in a higher social status, free from the domestic duties that she had been accustomed to, free from the hardships of her previous daily life. Her new status also earned her a new name, or rather a noble title: Mas Nganten. At first glance, from the patriarchal perspective, the main character of this novel was actually being liberated from her fate as a daughter of a poor family. She didn't have to work all day anymore; she ate better food, wore better clothes, and carried a higher social status. But Toer tells his readers that there was more than meets the eye; that liberating a woman from poverty does not automatically makes her happy, that issues of feminism do not always come in physical forms.

The researcher shall attempt to recognize Toer's perspective and to analyze the issues of feminism he portrayed in this novel, particularly 
through the aspects of marginalization, subordination, and stereotype.

\subsection{Marginalization}

The issue of marginalization was introduced early on in the novel. The Girl, as how Toer named her, was only fourteen when she was forced to marry the Bendoro, a prince of some sort belonging to Javanese nobility. A potential leap in both economic and social status made it impossible for The Girl's parents to reject the Bendoro's proposal to marry their daughter. The Girl's consent was out of the question. Her age was out of the question. Her teenage fear of being separated from her parents was out of the question. She was forced to leave her youth behind and marry a man she had never met.

From the first day of her marriage, The Girlhad to face the fact that her new status demanded so much to learn and so much to change:

"'You must not work while you're here. Your hands must be as soft as velvet. The first lady must always be refined."” (Page 16)

"'As first lady, you must learn to do everything which makes him happy. Never forget that." (Page 18)

"The first lady must learn to be clever. She must learn to be able to go against the tide." (Page 20)

"...the first lady must learn to be strong. She must hide all her feelings behind a smile." (Page 25)

As a 14-year-old, The Girl was forced to transform herself into a lady, to leave everything she had been accustomed to. She used to do household chores with her family, play with friends and neighbors. Now she had to live by herself, accompanied only by servants who could never replace the family, friends and surroundings she once had:

"She felt like a hen torn away from her brood. Living alone, yet surrounded by so many people. Not allowed to have friends. Simply giving and receiving orders, at the appropriate time. She felt so lonely. So cold." (Page 26)

Even The Girl's mother told her 14-year-old daughter that she was on her own:

“...From now on, you must learn to weep alone. No one else will see or hear you. You must learn to please others." (Page 41)

As suddenly as her change of status, The Girl was forced to grasp the reality that she now existed only as entertainment to others. She had to please not just her husband but her new surroundings.

\subsection{Subordination}

Subordination is perhaps the most obvious and most recurrent issue of feminism in this novel. However, Toer does not make his main character the only object of subordination; he focuses instead on the larger picture of subordination in the Javanese society: the subordination by the nobility towards commoners. One needs to take a closer look at this novel to find instances of subordination in a feminist sense.In this regard, the researcher of this thesis has selected the following quotes for analysis:

"How do I serve the Bendoro?'

"How? Obey him and do everything he tells you."' (Page 35)

The Girl learnt from the first time that being the wife of a noble did not free her from subordination. She may be a first lady, a wife to a noble; but a wife nevertheless. She had servants to do her biddings, but still she could not do anything without her husband's permission.

"Even if she lives in a shabby old hut, even if she isn't happy, a woman's sole duty is to learn to make her husband happy." (Page 41) 
This piece of motherly advice shows how patriarchal societies - be it commoners or nobles - all share a common view towards women. A wife exists not as an equal partner of life to her husband, but merely as a man's accessory. In the eyes of patriarchal societies, women are born into this world to complete men's lives.

"You belong to me. I decide what you can and cannot, will and will not do." (Page 89)

This last excerpt perhaps shows the worst kind of subordination. The Girl was less than a wife to the Bendoro; she was a concubine. She was less than a woman; she was a commoner. It was this status that had denied her the humane right to equality to men.

\subsection{Stereotype}

Toer'sThe Girl from the Coast is set on an Islam-influenced Javanese society. This society comprises hardworking commoners and wealthy nobles, the former consciously bound to unquestioning reverence to the latter. Toer has introduced some very interesting stereotypes toward the socially-accepted truths about life, coming from this centuries-old patriarchal culture.

Of course, amidst the many false assumptions and stereotypes in the novel, the researcher of this thesis attempts to center the analysis on stereotypes attached to women.

"You'll be the wife of a pious man. He has made the pilgrimage to Mecca. Who knows how many portions of the Koran he can recite by heart? When a woman marries, child, she becomes bad if her man is bad, and good if he is good. What fault can one find in him?" (Page 3)

The Girl's mother, as implied in the quote, believed in two socially- accepted assumptions: first, a man who had gone to Mecca for pilgrimage is a good man. Second, a woman who marries a good man is a good woman. The latter assumption brands a stereotype on women as not being able to be good or bad on their own accord. It all depends on the man she marries. A woman is deemed incapable of deciding for herself whether she wants to be good or bad.

\section{Mas Nganten's struggles to abolish patriarchal oppressions}

The main character of Toer's The Girl from the Coast is nameless. Toer simply called her "The Girl". Mas Nganten is the Javanese aristocratic title she received upon marrying the Bendoro - a Javanese noble. The researcher of this thesis chooses hereinafter to call the main character 'Mas Nganten' to avoid bias and ambiguity when referring to "The Girl" in the discussions.

Indeed, the pacifist nature of the Javanese culture that was the cultural setting of the novel and in particular the colonial status of the society under Dutch rule contributes a great deal to Mas Nganten's passiveness toward the oppressions. There was a Javanese role model for feminism, RadenAjengKartini, whose reputation was already quite resonant in the era in which the story was set:

"The Girl's story is....most securely located in time and space through reference to the recent death of RadenAjengKartini (1879-1904)" (Avelin in Toer,1991:introduction).

However, Kartini's influence, being a noble herself, seemed to only vaguely reached the common folks. To them, commoners' obedience to the aristocrats, as well as women's obedience to men, was a divine mandate: 
"Perhaps Allah created woman, Mas Nganten, so that man could beat her." (Page 61)

"Mbok... how would it be if everyone was rich? Or poor, without distinction?"

"That's impossible! [...] It's blasphemy. [...] God created heavens and the earth, [...] He made the day and the night. He made angels, and $\mathrm{He}$ made demons and evil spirits. He made high and $\mathrm{He}$ made low. If everyone was poor, or rich, why would $\mathrm{He}$ have commanded men to give tithes and alms? How would we know who the servant was and who the master? It would be the end of the world, Mas Nganten. Perhaps it would be a sign that the Day of Judgment is near." (Page 61)

While maintaining the Javanese commoner stereotypes to Mas Nganten being passively obedient to patriarchal aristocrats - Toer had chosen to refrain from portraying open conflicts between his main character and the male oppressor, saving it instead for the climax of the story. Throughout the early periods of the story Mas Nganten remained an inquisitive fourteen year-old who questioned the obedience of common folks to the nobles but never dared to openly oppose her noble husband. Her struggles against patriarchal oppressions throughout the plot largely took place in her inner self. She was powerless to voice her objections to her husband the Bendoro. She had to brush aside her doubts and remained true to her parents' expectations, and resumed her role as a good wife.

The underlying climax of the story happened when Mas Nganten was divorced immediately after giving birth. She knew that she had only been a 'practice wife' for the Bendoro until he had found a noble woman of his stature,

"A Bendoro who had married a commoner was not considered married at all, even if they had a dozen children. Such a marriage was only a preparation for the noble's proper marriage - to a woman of his same social standing." (Page 50)

but throughout her marriage no one told her that she would be divorced if she ever bore a child. Aristocratic tradition wouldn't permit a commoner to have a baby with a noble. Mas Nganten was not allowed to keep the baby; she was not even allowed to see the child ever again. She was banished from the Bendoro's mansion.

"You want me to go, tuanku, without my baby?"

"I told you: you don't have a baby. You never had a baby."

"Yes, Bendoro."

"Now go."

"But the money and jewelry is worthless without my baby, Bendoro." "Then give them to the baby."

Neither The Girl nor her father knew what to say.

(page 176)

Mas Nganten was powerless to fight this oppression, yet she still managed to display her last stand. She decided to leave her parents, breaking free from the pitiful stare of her neighbors and friends in the village. She left the region altogether, and started a new life completely on her own.

"Bapak, I can't go back to the village. I'd rather go somewhere a long way away."

The Girl from the coast kneeled and kissed her father's feet. Her kain was covered in wet sand.

"Forgive me, bapak. I wouldn't be able to face emak, our neighbors, or anyone else in the village. Forgive me. I want to be on my own." (page 184)

It is worth noticing, however, that in her last words to her father before leaving him she suggested a rather sarcastic conviction that he could buy a boat with the money he got from the 
Bendoro, and that the boat would easily replace her:

"Buy a boat. They make good boats in Lasem. It will be your child. ...Consider me dead, if you want. The boat will make you prouder than any of your children will." (page 184)

This could imply that Mas Nganten also wanted to punish her father by leaving. Indeed, he was also a part of the patriarchal oppressors. If it weren't for her parents, Mas Nganten would not have to marry the Bendoro and go through all that suffering. Leaving her family may not be a victory in her struggles against patriarchal oppressions, but living independently is as close as she can get to a freedom.

\section{Main characters' struggles to abolish the impacts of gender inequity}

The Girl suffered from the impacts of gender inequity. The novel describes how of main character had struggled to abolish these impacts; sometimes with short-lived triumphs, but most of the time to no avail. Mas Nganten in Toer'sThe Girl from the Coast probably had the least amount of conflicts. The author chose to base the power gap in the story on the disparity of power between Javanese aristocrats and commoners, and put little spotlight on gender inequity. The nobles looked down not only at The Girl, but also at her parents and her people. As a wife she was considered inferior not only because she was a woman, but more because of the assumption of divine authority that the nobles had over the commoners.

Thus, most of The Girl's struggles happened in her inner self. She questioned her husband's and the nobles' authority, but couldn't do more than that as she was made to believe that a commoner was deemed powerless by fate. Ultimately, her inner struggles came to a culminating point when she was divorced immediately after giving birth. She was not allowed to keep her baby, because aristocratic tradition wouldn't permit a commoner to have a baby with a noble. Powerless to do anything about it, The Girl's last resolve to the injustice was to leave everything behind; including her parents. This was the only way she knew to salvage what remains of her dignity; she left her parents, her family, her village, to start a whole new life on her own.

\section{CONCLUSION}

After analyzing the main character of Ananta'sThe Girl from the Coast, I arrive to several conclusions in respect to the individual problems Toer'sThe Girl from the Coast portrays The Girl's tiresome yet fruitless struggle against the patriarchal oppressions in her unequal marriage. She had to face one injustice after the other, climaxing to the point where she had to give up her new-born baby because the Javanese aristocratic rule commanded immediate divorce of a concubine while confiscating her baby. In her last effort to save dignity, she opted not to return to her family and chose to live by herself. As an overall conclusion, Toer portrayed in his respective novel, the author share one common message: that there was no victory for a woman who struggles against a patriarchal oppression, except she was willing to leave her life behind.

This suggestion consists of two parts: Suggestion for future researches and English teachers. The first part of this section concerns future researchers interested in literary works. Considering that literary work can be the mirror that shows the condition of society, there are a lot of aspects on the novel that will be very interesting to be analyzed. Issues of feminism are an interesting and challenging subject to be explored and analyzed. They reveal the story beyond the 
story in the novels. However, there are still many other elements of the novel that are not covered in this study and that can be interesting for future researchers to analyze. This article can function as a stepping stone for such purpose. The second part of this section concerns the implementation of literary work in teaching-learning implementation. Literature brings benefits for language teaching-learning process because it represents the advanced and artistic use of language. It provides the chance for students to explore the language for academic purposes as well as creative needs. In essence, literature provides its readers with knowledge, pleasure, and realization of the values of life.

\section{ACKNOWLEDGEMENTS}

I would like to express my deepest gratitude to committee International Seminar and Workshop from UPI Bandung for their continued support and encouragement, offer my sincere appreciation for the opportunities provided by committee. A thankyou to Madura University especially Teacher Training and Education Faculty forthe attention and chance so I could participation in International seminar and Workshop tocreate this article. Finally, my greatest respect and thanks are addressed to my husband for your support, my daughter and my son for their love and togetherness, my mother, my brothers and my sisters for their pray, and to others who are not mentioned here for their encouragements and unforgettable affections.

\section{REFERENCES}

Magnis-Suseno, Franz. 2003. Pemikiran Karl Marx: dari SosialismeUtopiskePerselisihanRevi sionisme. Jakarta: PT. Gramedia Pustaka Utama.

Ratna, Nyoman Kutha.2009. Teori,Metode,dan Tehnik Penelitian Sastra: dari Strukturalisme hingga Postrukturalisme. Yogyakarta:pustaka Pelajar.

Toer, Pramoedya.A.1991. The Girl from The Coast (translated by HaryyAveling) .Singapore:select Books.

Wikipedia.2008."Marxist Literary Criticism" pada laman: http://en.wikipedia.org/wiki/Marxis t literary criticism diakses pada 7 March 2011. 